\title{
Transitar hacia la paz en Colombia. Entre la promesa y la ilusión en dos experiencias históricas (1953-2017)*
}

\author{
Transition toward the Peace in Colombia. Between Promise and Illusion in Two Historic Experiences (1953-2017) \\ Rumo à paz na Colômbia. Entre promessa e ilusão em duas experiências históricas (1953-2017)
}

\author{
Jefferson Jaramillo Marin ${ }^{\text {a }}$ \\ Pontificia Universidad Javeriana, Colombia \\ jefferson.jaramillo@javeriana.edu.co \\ ORCID: https://orcid.org/0000-0002-0016-7631
}

Érika Paola Parrado Pardo

Pontificia Universidad Javeriana, Colombia

ORCID: https://orcid.org/0000-0001-5434-1132

Alexander L. Fattal

Universidad de California, Estados Unidos

ORCID: https://orcid.org/0000-0001-8425-0215
DOI: https://doi.org/10.11144/Javeriana.syp39-77.thpc

Recibido: 06 Abril 2020

Aceptado: 17 Septiembre 2020

Publicado: 30 Diciembre 2020

\section{Resumen:}

En 1953 y entre 2012 y 2016 tuvieron lugar en Colombia dos procesos históricos de paz que involucraron, de una parte, a las Guerrillas Liberales del Llano y de la otra, a las Fuerzas Armadas Revolucionarias de Colombia. Haciendo uso de un corpus de imágenes derivado de medios de comunicación como El Tiempo y la revista Semana, así como del Archivo Germán Guzmán Campos, y acudiendo a literatura secundaria y a claves de lectura derivadas de los estudios sobre imagen y performance se discute sobre el sentido y alcances de la representación habitual de estos como "tránsitos hacia la paz". Lo propuesto en el artículo deriva de un proyecto de investigación reciente sobre memoria histórica y práctica visual financiado por la Universidad Javeriana entre 2015 y 2018. La principal contribución está en avanzar críticamente en la discusión sobre el carácter de porosidad y simulación de la paz pactada en ambos momentos históricos, más allá de los logros políticos y alcances sociales sobre los que se centran los análisis habituales.

Palabras clave: paz, transición, performance, experiencia histórica de paz, Colombia.

\section{Abstract:}

In 1953 and later between 2012 and 2016, two historic peace processes took place in Colombia involving the Liberal Guerrillas from the Plains, on the one hand, and the Colombian Revolutionary Armed Forces, on the other hand. Using a corpus of images taken from media outlets like the newspaper El Tiempo and the magazine Semana, the Archive Germán Guzmán Campos, and searching in secondary source literature and some reading keys derived from studies on image and performance, this article discusses the sense and scope of their usual representation as "a step toward the peace". The point stated herein comes from a recent research project on historic memory and visual practice sponsored by the Universidad Javeriana between 2015 and 2018. The main contribution consists in making a critical progress in the discussion on the nature of porosity and simulation of peace as it was agreed on in the two aforementioned historic events. It is considered beyond the political achievements and social goals that the usual analyses use to be focused on.

Keywords: peace, transition, performance, historic peace experience, Colombia.

\section{Resumo:}

Em 1953 e entre 2012 e 2016 ocorreram na Colômbia dois processos históricos de paz que envolveram, de uma parte, às Guerrilhas Liberais do Llano e da outra, às Forcas Armadas Revolucionárias da Colômbia. Utilizando um corpus de imagens derivado de meios de comunicação de massa como o jornal El Tiempo e a revista Semana, bem como o Archivo Germán Guzmán Campos, e recorrendo à literatura secundaria e a chaves de leitura derivadas dos estudos sobre imagem e performance discute-se o sentido e escopo da representação habitual destes como "trânsitos para a paz". O proposto no artigo decorre de um recente projeto de pesquisa sobre memória histórica e prática visual financiado pela Universidade Javeriana entre 2015 e 2018. A principal contribuição está

Notas de autor

\footnotetext{
${ }^{a}$ Autor de correspondencia. Correo electrónico: jefferson.jaramillo@javeriana.edu.co
} 
no avanço crítico na discussão sobre o carácter de porosidade e simulação da paz pactuada em ambos os momentos históricos, para além das conquistas políticas e escopos sociais em que centram-se as análises habituais.

Palavras-chave: paz, transição, performance, experiência histórica de paz, Colômbia.

\section{Introducción}

En 1953 y entre 2012 y 2016, acontecieron en Colombia dos procesos históricos de paz con grupos armados: las Guerrillas Liberales del Llano y las Fuerzas Armadas Revolucionarias de Colombia. Ambos procesos, aunque diferentes en sus particularidades contextuales y distantes cronológica y políticamente, tuvieron algo en común: quedaron emblematizados en las memorias de los procesos de negociación en el país (Guzmán et al., 1962; Franco, 1994; Villanueva, 2012; Zapata et al., 2018; Presidencia de la República, 2017, 2018). Al igual que pasó con otros procesos de paz en el país, se tiende a representarlos habitualmente por académicos y sectores políticos como tránsitos hacia la paz.

Los especialistas en justicia transicional se inclinan a considerar que tras la firma de la paz con un actor armado devienen una serie de condiciones, no de manera lineal ni secuencial, pero sí con cierta holgura en el tiempo: desarme, desmovilización y reintegración (DDR). La literatura enfatiza que estas tres esferas no son componentes aislados dentro de una operación de paz, sino condición necesaria para superar una confrontación armada, minimizar riesgos y brotes de violencias en un período posacuerdo y, en suma, sustentar la construcción de paz (Joya, 2015).

Ubicados desde una distancia reflexiva frente a lo planteado en la literatura de DDR, la propuesta de este artículo, algo modesta, es contribuir con pistas provisionales sobre el sentido performático de una figura común para calificar estos procesos: la del tránsito hacia la paz. Interesa destacar y analizar dos momentos de este tránsito. En primer lugar, la promesa de la paz que convoca al Estado y al actor armado, no solo para la entrega de las armas, sino para el compromiso y garantía de no retorno a las armas o garantías de no rearme. En segundo lugar, la ilusión de la esperanza que deviene luego de estos procesos y en la que convergen utopía y distopía frente a un modo de vida más allá de la guerra.

Lo escrito es producto del intercambio de los autores, en torno a varios recursos: a) un corpus de imágenes derivado de periódicos como El Tiempo, El espectador, la revista Semana y el Archivo Germán Guzmán Campos, sobre procesos históricos de paz ocurridos en Colombia entre 1953 y 2017² b) la discusión en relación con una literatura secundaria sobre estos dos eventos y c) algunas claves de lectura derivadas de los estudios sobre imagen y performance. El marco general de lo escrito fue un proyecto de investigación sobre memoria histórica y práctica visual financiado por la Universidad Javeriana entre 2015 y 2018.

Metodológicamente se optó por seleccionar estos dos procesos a modo de ilustración de lo que habitualmente se considera son procesos de DDR con relativo éxito, y que permiten contar con fotografías relativamente similares, respecto al momento de la entrega. Inicialmente, se realizó un barrido documental tanto de fuentes secundarias y primarias de diversa índole, entre ellas se encuentran diversos periódicos impresos nacionales y locales, para comprender las dinámicas contextuales de ambos procesos. La selección de las imágenes tanto de El Tiempo como de El Espectador derivó de aquellas fotografías representativas de estos momentos históricos a modo performativo. Por su parte, la bibliografía secundaria se seleccionó a partir de cuatro ejes: enfoques y perspectivas de los estudios de paz, procesos de DDR, procesos históricos de paz en Colombia y reflexiones teóricas sobre imagen y perfomance.

Como precaución importante para quien se aventure al artículo: no es, ni tiene la intención de ser, un producto derivado de una investigación histórico-sociológica sobre dos procesos de paz o de sus vicisitudes políticas; no pretende ser un trabajo comparado, ni prescriptivo de lo que debieron ser estos dos momentos o convertirse en un artículo sobre su memoria visual. Es solo un escrito-provocación que convoca a detener la mirada y el análisis en lo que puede estar implícito o explícito con la figura del tránsito, y proponer una 
discusión crítica sobre el carácter hipersimbólico y por momentos simulado de la paz en Colombia y, por qué no, de la enorme porosidad de ese tránsito como ceremonial passage. El material visual, de archivo y de fuentes secundarias recogido, analizado y discutido, fue finalmente ensamblado en la escritura solo con esa intención.

\section{La paz como tránsito}

Dentro de los estudios de paz son múltiples las aproximaciones conceptuales respecto al cómo se ha entendido esta categoría. De una parte, están las reflexiones pioneras de Johan Galtung $(1990,1996)$ y Vicent Fisas (1998) a propósito de la relación conflicto y paz y las nociones de paz negativa y paz positiva; también se encuentran las propuestas que intentan complejizar la paz liberal como la de paz imperfecta (Muñoz, 2004), o la de paz posliberal y paz hibrida (Doyle, 2005; Pérez de Armiño y Zirion, 2019; Richmond, 2006, 2011). Otras perspectivas enfatizan en el giro local como el de paz cotidiana (Mc Ginty, 2014), la paz subalterna o la paz decolonial (Cruz y Fontan, 2014; Fontan, 2013). Este texto en específico se centra en una de las vetas analíticas de los estudios de paz a secas, que son los procesos de DDR.

Los especialistas en justicia transicional consideran que tras la firma de la paz con un actor armado devienen una serie de condiciones. A estas se les conoce como Desarme, Desmovilización y Reintegración (DDR). Estos conceptos a su vez han sido impulsados por las Naciones Unidas, con expresiones como las de peacemaking, peacekeeping y peacebulding. Movilizadas por esta organización supranacional, estas condiciones se enmarcan en lo que se conoce como la "Agenda de Paz" que en 1992 esbozó el entonces Secretario General Boutros Boutros Ghali (Knight, 2008; Schulhofer-Wohl \& Sambanis, 2010). Bajo esta agenda, el desarme se entiende "como la recolección, control y eliminación de municiones, explosivos y armas, mediante el desarrollo de un programa de entrega, almacenamiento y destrucción o protección- cuando estas quedan en manos de alguna organización responsable de decomisarlas"2 (Knight, 2008, p. 28). La desmovilización, por su parte, se concibe como el acto de disolver una organización o una estructura militar por parte de un grupo armado inmerso en un conflicto, lo que exige "la concentración de tropas en sitios de acantonamiento, campamentos, cuarteles y demás áreas, además implica que los excombatientes renuncien a sus armas”3 (Knight, 2008, p. 29).

El puente entre la acción de entregar las armas y el proceso posterior es la reintegración, siendo el momento de mayor duración y complejidad en tanto acción económica y social, que posibilita al excombatiente y a su familia insertarse en la vida civil a nivel comunitario e institucional. Este proceso implica la provisión de formas de compensación que representen un incentivo para el no retorno a las armas, lo que exige:

[...] proporcionar a los excombatientes capacitaciones laborales o profesionales a largo plazo e incentivar proyectos sostenibles

de generación de ingresos [...] esta etapa del proceso de DDR se acompaña por esfuerzos de rehabilitación de personas afectadas por la guerra y la reconstrucción de la infraestructura nacional. (Knight, 2008, p. 29)

Los gestores y expertos en procesos de paz son conscientes de las enormes tensiones derivadas de los diseños institucionales que hacen posible el DDR. El tránsito de la condición de guerrero a la de excombatiente exige reformas institucionales y programas estatales que garanticen la reintegración e inserción a la sociedad de los desmovilizados, así como la garantía de sostenibilidad económica y, principalmente, de seguridad para los excombatientes. Pero esto, no siempre opera como se esperaría dentro de los diseños institucionales concebidos para ello, ni en las voluntades políticas para hacerlo posible y efectivo. Colombia es un claro ejemplo histórico de ello. Sin desconocer, por supuesto, los logros y avances en distintos procesos de paz que han tenido lugar en el país son innegables las sombras de nuestra paz: el asesinato posterior de excombatientes, las frecuentes amenazas y los desplazamientos de los reintegrados (Villarraga, 2013, p. 122), su rearme bajo la forma de disidencias y las sensaciones no tan positivas, de excombatientes, sobre sí mismos, el futuro y las herramientas para lograr la reconciliación (Arjona et al., 2020).

La literatura sobre el denominado DDR es bastante profusa así como abierta la discusión sobre lo que un proceso de paz significa, engloba e implica; también diversas las normas, guías, 
buenas y malas prácticas, y aprendizajes ocurridos en el mundo (Gleichmann et al., 2004). En el país, se han realizado balances históricos de logros y pendientes de estas distintas fases de procesos de paz ocurridos a partir de $1953^{4}$, no obstante, el trabajo de Nussio $(2012,2013)$ es bastante sugerente, por cuanto rastrea los diversos momentos de los ejercicios del DDR en Colombia, reconociendo tres olas: una primera, orientada a la implementación y técnica de los procesos de DDR, una segunda, interesada en cuestionar la efectividad de estos y situarlos contextualmente, incorporando reflexiones acerca de la relación seguridad y desarrollo y una tercera, donde el foco ha sido el lugar del excombatiente.

Lo que no es tan común ni preponderante dentro de los análisis convencionales es la reflexión sobre la significación social y cultural de estos procesos y, menos aún, sobre el sentido performativo y de teatralidad social que engloba el tránsito hacia la paz. Como han reconocido algunos investigadores, desarme, desmovilización y reinserción son piezas de todo un engranaje, pero no hay que pasar de soslayo para un país, la experiencia de transitar que implica pasar de combatiente a excombatiente. Esta experiencia tiene hondas repercusiones en los sujetos transicionales y en los escenarios transicionales (Theidon y Betancourt, 2006) y en la forma en cómo en el país hemos experimentado, ritualizado, simbolizado y burocratizado la paz (Fattal, 2019).

\section{Performance e imagen}

La literatura canónica sobre procesos de paz enfatiza en mayor o menor medida los diseños o arquitectónicas institucionales (políticas, jurídicas, económicas y sociales) que pueden hacerlos viables o inviables para un país. La propuesta de este artículo va en otra dirección. Consiste básicamente en prestar atención a la dimensión performativa imbricada en la idea de tránsito hacia la paz. Retomando a Taylor $(2011,2012)$ se concibe el performance, como un proceso, práctica, acto, episteme, evento, modo de transmisión, desempeño, realización y medio de intervención en el mundo, en los que se ponen en juego múltiples formas de ruptura con la convención y lo establecido, pero también poderes que modelan y domestican lo cotidiano. Más que como género artístico, interesa la performance como "una lente con la cual observar el desempeño de roles, la significación de normas y rituales" (Verzero, 2020, p. 219), como "un lugar posdisciplinar" para leer "las prácticas, los actos, rituales, juegos y enunciaciones, el archivo (la memoria documental) y los repertorios (la memoria corporal" (Taylor, 2011, pp. 13-14).

Somos conscientes que anclar aquí nos conduce por el camino de comprensión de la paz no en su ingeniería y diseño, sino dentro de la significación social y cultural de un conjunto de rituales, actos, epistemes que operaron para ello en determinados momentos históricos, de lo que estos simbolizaron para el Estado o para los que entregaron sus armas, de las promesas que los hicieron posibles o inviables, de las formas como se nombraron y entendieron estas promesas o esperanzas y, por supuesto, de las incertidumbres generadas a posteriori. La categoría de performance problematiza la condición de representacionalidad de lo real, sin negar claro está la representación, acercándonos más a la intención de pensar la paz como experimento, como ensamble, como simulación.

El recurso para evidenciar esto en el artículo, es un conjunto de imágenes de archivo, de nuevo siguiendo a Taylor (2011) como sistema de transmisión de los sentidos performáticos de lo sucedido en estos dos momentos históricos. Es decir, interesa no tanto lo que la imagen evidencia o demuestra, sino el lugar que ocupa en diversos productos culturales (en nuestro caso, por ejemplo, un periódico, un archivo personal), las afectaciones que produce y los rituales que encarna. Como parte de esa arquitectura de la verdad, un ejercicio sustantivo es el ejercicio del rever, es decir, "observar detenidamente una imagen en sus partes, en sus detalles, en sus fragmentos aislados, en las relaciones que recrea” (Guarín, 2019, p. 309). El rever, siguiendo libremente 
a Didi-Huberman (2012), significaría reconocer, recrear los espacios vacíos o las zonas grises entre imágenes, o sea, lo que permanece en silencio entre una imagen y otra, entre un momento histórico y otro 5 . En este caso, esto podría ayudar a situar en escena lo que pasa desapercibido o simplemente no cuenta o resulta factor menor para los diseños institucionales o el arte de gobernar -statecraft- en un proceso como estos (Theidon y Betancourt, 2006).

Al examinar imágenes sobre la violencia en Colombia, Guarín (2019) con una fotografía de Jesús Abad Colorado de un campesino de Urabá que yace asesinado en plena vía pública ante el desinterés de los transeúntes y, Fayet y Gordillo (2017) con fotografías de soldados rondando espacios públicos y comunitarios en San Carlos (Antioquia), Toribío (Cauca) y Buenaventura (Valle del Cauca), se enfocan, sin explicitarlo, también en el sentido performativo de las imágenes. Se referencian estas dos investigaciones, porque la violencia emerge allí a través del exceso, la repetición y la sobrerrepresentación ${ }^{6}$, operando efectos de verdad en el régimen de visibilidad del conflicto armado. Como dice Olaya (2020) una sobrevisibilidad del horror, termina siendo inmovilizadora. En ese orden de ideas, uno de los principales efectos de verdad o efectos performáticos, es la funcionalidad que esto representa para ciertos sectores, por ejemplo, para el Estado. La consecuencia de ello es el aplanamiento de la comprensión de lo sucedido. Esto mismo, posiblemente, ha ocurrido con la paz.

\section{Un poco de historia y de contexto}

En su historia reciente, el país ha transitado al menos por trece experimentos institucionales de paz, algunos exitosos, otros fallidos ${ }^{7}$. Cada experimento representó una oportunidad política y un escenario de tensiones. En algunos casos, se silenciaron parcial o totalmente las armas de los grupos armados, en otros, operó más la simulación de lo transicional. En algunos momentos, se intentó conjurar gubernamentalmente la guerra con políticas de reconciliación, en otros, con estrategias de pacificación. En algunos casos, se cerró el pasado incómodo sin políticas de memoria, en otros se sobregestionó y administró institucionalmente el pasado doloroso de las víctimas. Dos posibles ejemplos de esto los tenemos en la paz firmada con las Guerrillas Liberales del Llano (1953) y con las Fuerzas Armadas Revolucionarias de Colombia (2016).

Hacia la década de los años 40, los Llanos Orientales colombianos constituían una región relativamente marginal del proyecto estatal, y el poder estaba en manos de hacendados y ganaderos. Tras el asesinato del líder liberal Jorge Eliécer Gaitán (1948), como va a suceder en otras ciudades del país, comienzan a consolidarse viejos focos de resistencia o a emerger nuevos en varias regiones. El primer foco de resistencia armada en esta región, luego del "gaitanazo"8 ocurre bajo la forma de una Junta Revolucionaria liderada por el líder gaitanista Eliseo Velásquez, quien años más tarde, en septiembre de 1952 sería asesinado luego de haber sido deportado de Venezuela donde había sido capturado en 1950. Entre 1949 y 1951, se crean y organizan varios comandos guerrilleros en Acacías, San Martín, Restrepo, Puerto López, Villavicencio, y entre otras ciudades (Villanueva, 2012), en una "una típica reacción de autodefensa liberal contra la violencia estatal y conservadora que hizo presencia en la zona después del 9 de abril” (Valencia, 2018, p. 23).

En su germen, esta resistencia llanera estuvo liderada por comandos guerrilleros que eran grupos muy heterogéneos integrados por dueños y trabajadores de haciendas, así como ganaderos, y estuvo apoyada por líderes emblemáticos como José Alvear Restrepo. Algunos de estos comandos fueron liderados por grupos familiares, sin unidades de mando claras, destacándose los de los hermanos Fonseca, los hermanos Roa, los hermanos Bautista, entre otros. Entre el 11 de septiembre de 1952 y el 19 de junio de 1953, luego de varias fracturas e intentos de estructura orgánica, las guerrillas llaneras van a expedir dos leyes que les permiten reglamentar su organización y crear su propio marco local para su revolución. Con la "Primera Ley del Llano" se organizará el Comando Guerrillero de los Llanos Orientales bajo el liderazgo de Eduardo Franco Isaza. 
Con la "Segunda Ley del Llano" se elegirá a Guadalupe Salcedo como único Comandante en Jefe de todas las fuerzas guerrilleras de la región.

Con las guerrillas del Llano hubo varios intentos de negociación desde 1951, pero será la llegada de Gustavo Rojas Pinilla al poder el 13 de junio de 1953, luego de un golpe de Estado a Laureano Gómez pactado entre las élites para frenar La Violencia, la que "selle", expresión muy común para la época en los medios de comunicación, una política de pacificación para la zona y el país. La ratificación de este proceso se dará con el Decreto de Amnistía 1546 del 22 de junio de 1953 y 10 eventos de entregas de armas en distintas zonas del Llano que acontecerán entre el 9 de septiembre y el 21 de septiembre de 1953.

Por su parte, la llegada de Juan Manuel Santos a la presidencia en 2010, abrió un marco de oportunidad política para una negociación efectiva con la que hasta ese momento era la guerrilla moderna más antigua del Continente, las FARC-EP. Durante el Gobierno de Álvaro Uribe Vélez este proceso no había sido posible por el clima de tensión y polarización entre ambas partes. Y durante Gobiernos previos, varios experimentos de diálogo y negociación habían sido parcialmente exitosos y con altos costos para el país: la Uribe (Meta) y San Vicente del Caguán (Caquetá).

En el 2012, el Gobierno de Santos mantuvo acercamientos exploratorios y conversaciones secretas con esta guerrilla durante algunos meses. Esto permitió la construcción de una hoja de ruta para el inicio de un proceso de conversación en Oslo (Noruega). Este país fue el primer peldaño de un camino que terminaría en La Habana (Cuba), y que posibilitó la firma de una agenda de negociación, la conformación de equipos asesores y, a la vez, el establecimiento de un marco de comprensión básico entre las partes (Presidencia de la República/ OACP, 2018). Este proceso de idas y venidas vivió múltiples momentos de tensión entre los negociadores, porque además se estaba adelantando en medio del conflicto, con escaladas y desescaladas permanentes de las acciones de violentas entre ambas partes; no obstante, esto nunca generó rupturas totales dentro de la mesa de negociación ${ }^{9}$, lo que conllevaría a su culminación cuatro años después del inicio de las conversaciones, y a la firma de un Acuerdo de Paz. Este evento tuvo lugar el 24 de agosto de 2016 en Cartagena.

El tránsito no terminaría allí, dado que luego vino un proceso de refrendación de este a través de las urnas, mediante un plebiscito que permitiera su aprobación. Los resultados del plebiscito del 2 de octubre del 2016 fueron insólitos, ganando el NO con un poco más del $50 \%$ de los votos, en una contienda donde la diferencia con el SÍ, fue de apenas 53894 votos. Este resultado que, al decir de algunos analistas, reflejó las enormes paradojas emocionales (Gómez-Suárez, 2016) en las que nos movemos los colombianos, hizo necesario someter nuevamente el acuerdo a un proceso de reajuste con la oposición que terminó con algunas modificaciones a lo pactado inicialmente y el refrendamiento definitivo por el Congreso (British Broadcasting Corporation $[\mathrm{BBC}], 2016)$. Este se hizo público y fue firmado nuevamente el 24 de noviembre del mismo año. De todos los procesos de paz acontecidos en el país, este sería uno de los de más resonancia internacional e impacto mediático en la historia del país.

\section{Las promesas: paz, justicia y libertad (1953; paz duradera y estable (2017}

En toda promesa siempre hay ofrecimiento u oferta de algo entre unas partes, a mediano o largo plazo. Siempre hay un acto de fe, un salto a la creencia. En el caso de los actores armados que entraron en procesos de negociación con el Estado, esto se tradujo históricamente en un conjunto de ofertas institucionales orquestadas dentro de un régimen de normalización democrática y burocrática. La fórmula ha sido más o menos la siguiente: aquel que opte por la paz, entregue las armas y se desmovilice puede insertarse nuevamente en este régimen y volver a ser parte de su proyecto. Esto sucedió en los Llanos con las Guerrillas Liberales y volvió a acontecer con las FARC, recientemente. Examinemos lo anterior a la luz de lo sucedido entre septiembre y octubre de 1953, luego de pactada la amnistía con las guerrillas y en junio de 2017, luego de firmada la paz con las FARC. 
Tras varias conferencias pro paz y la concentración de los revolucionarios llaneros en Monterrey (Casanare), el comando de los hermanos Fonseca se entregaría con hombres y armas el día 9 de septiembre de 1953 en Tauramena (Casanare) (Figura 1). En una carta remitida por Eulogio Fonseca, muy diciente por cierto del sentido de la promesa y respondiendo a la pregunta ¿Por qué entrego mi fusil?, él argumentaba: "porque se me brindaron las garantías desde el 1 de junio de 1953, porque el Gobierno nos ha tendido una mano franca y generosa y porque anhelo poder vivir en mi territorio con Paz, Justicia y Libertad"10 [cursivas fuera del texto]. Con esta carta, Fonseca se colocaba a plena disposición de las órdenes del General Alfredo Duarte Blum, y ratificaba que se creía en la promesa del Gobierno. Esto ocurría para el país al amparo de una amnistía otorgada por el Gobierno de Rojas Pinilla bajo el Decreto 1546 del 22 de junio de 1953, la cual estaba enmarcada en una política de negociación-pacificación que había comenzado desde el año 1951 con varios de los comandos de estas guerrillas.

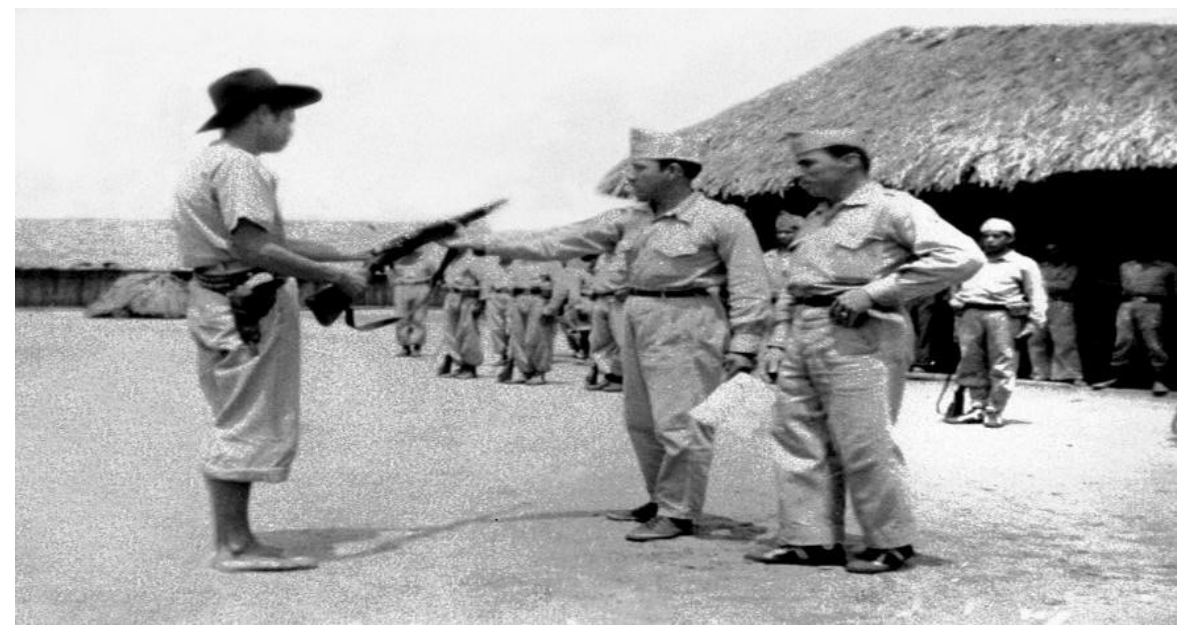

FIGURA 1.

El primer fusil entregado en el Llano por Eulogio Fonseca ante oficiales de Rojas Pinilla.

Fuente: Archivo Germán Guzmán Campos (2019).

A esta primera entrega le seguirán otras muy promocionadas para la época, por el valor simbólico que representaban tanto para el proceso revolucionario de los Llanos, como para el Gobierno de Rojas Pinilla contar con la claudicación formal de estas fichas políticas: la de Guadalupe Salcedo, en las Delicias (Casanare), el día 12 de septiembre y la de Dumar Aljure en San Martín (Casanare), al día siguiente (Figuras 2 y 3 ). Luego vendrán ocho entregas más. Según un informe del General Saiz Montoya al presidente Rojas Pinilla, entre el 9 y el 25 de septiembre se entregaron 464 armas, 12842 municiones y 1474 hombres $^{11}$. Estas entregas se hicieron, por lo general, en presencia del Brigadier General Alfredo Duarte Blum, comandante por ese entonces de las Fuerzas Armadas y del coronel Alfonso Saiz Montoya, jefe civil y militar de los Llanos.

En dichas entregas es central el rol de las Fuerzas Armadas, puesto que se consideraban a sí mismos y eran presentados en todos los medios como los custodios de la política de pacificación de Rojas Pinilla. Los guerrilleros, en cambio, la mayoría de las veces, eran presentados como bandoleros en armas o facinerosos terribles. A lo primeros, se decía, los acompañaba "el más alto y encomiable sentido patriótico para llevar al País por las sendas del orden, la justicia, el progreso". A los segundos "los caracterizaba la violencia y la mala $\mathrm{fe}{ }^{12}$. En la gestión de paz, los primeros debían normalizar a los segundos. 


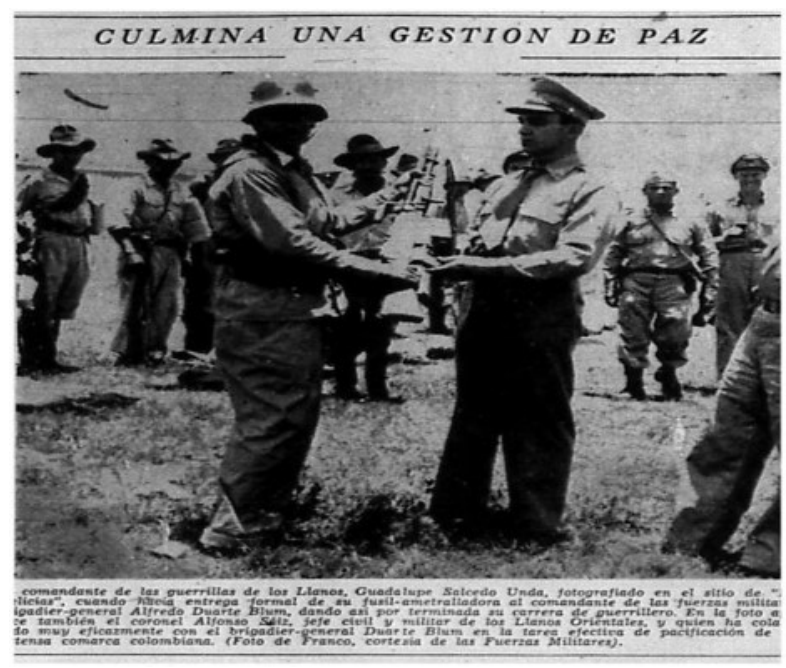

FIGURAS 2

Guadalupe Salcedo (izquierda) entregando sus armas a oficiales de Rojas Pinilla. Fuente: El Tiempo (16 de septiembre de 1953) y Archivo Germán Guzmán Campos (2019).

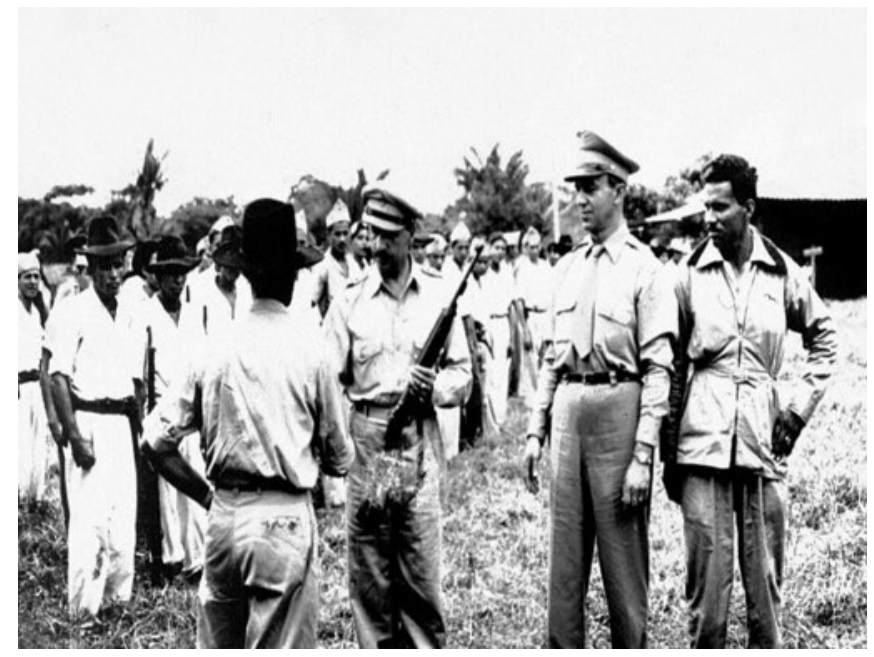

FIGURA 3.

Dumar Aljure (derecha) entregando sus armas a oficiales de Rojas Pinilla. Fuente: El Tiempo (16 de septiembre de 1953) y Archivo Germán Guzmán Campos (2019).

Sesenta y cuatro años después, el 27 de junio de 2017, la guerrilla de las FARC-EP, entregaría el último grupo de armas en su poder a la Misión de Verificación de la ONU. Esta entrega no había estado exenta de tensión durante el proceso de diálogo desde el 2012. Para el Gobierno la entrega física y total de las armas en poder de las FARC debía ocurrir antes de la firma de acuerdos y se convertía en una condición "innegociable para la reincorporación y evitar brotes de proselitismo armado posteriormente (El Colombiano, 25 de febrero de 2015 citado en Aguirre et al., 2015).

Para las guerrillas, en cambio, "por ningún motivo habría entrega física porque eso significaría claudicación; lo que ocurriría sería una dejación de armas" (Aguirre et al., 2015). Incluso, algunos de sus líderes llegaron a advertir en 2013 que "el Gobierno no tendría foto de entrega de las armas (El Colombiano, 7 de julio de 2013 citado en Aguirre et al., 2015) y que el Estado debería considerar también la dejación de sus armas. Antes que transición, lo que ellos apostarían sería a la normalización (Sitio web de las FARC, 24 de octubre de 2014 citado en Aguirre et al., 2015). 
Firmado el acuerdo final (el segundo acuerdo) y con las tensiones medianamente resueltas ${ }^{13}$ y un respaldo internacional que permitió aligerar las cargas, el acto del 27 se llevó en una ceremonia oficial, como lo exige un proceso de "desarme oficial", en zona rural del municipio de Mesetas, departamento del Meta. El acto estuvo acompañado, entre otros, por el presidente Juan Manuel Santos, el jefe de la Misión de la ONU en Colombia, Jean Arnault, y el líder de las FARC, Rodrigo Londoño. A diferencia de lo que había acontecido en el Llano, el presidente de la República presidía el acto y no los militares. Distintos medios de comunicación informaron que, con este acto, la organización había completado la entrega de más de 8000 armas, proceso que había iniciado por partes, entre el 7 y el 14 de junio de 2017.

Las Figuras 4 y 5 ilustran parte de esta liturgia. En la primera, además de las importantes personalidades que asisten a este momento paradigmático, aparecen en foco las manos de los otrora enemigos que se juntan ahora para sellar un pacto; la escena es acompasada por un arma que fuera instrumento de guerra, convertida ahora una herramienta futura de trabajo, como símbolo de una paz estable y duradera. En la Figura 5, se observa claramente el lugar que tiene la misión de la ONU como custodio del registro, el etiquetaje y el embale del armamento entregado.

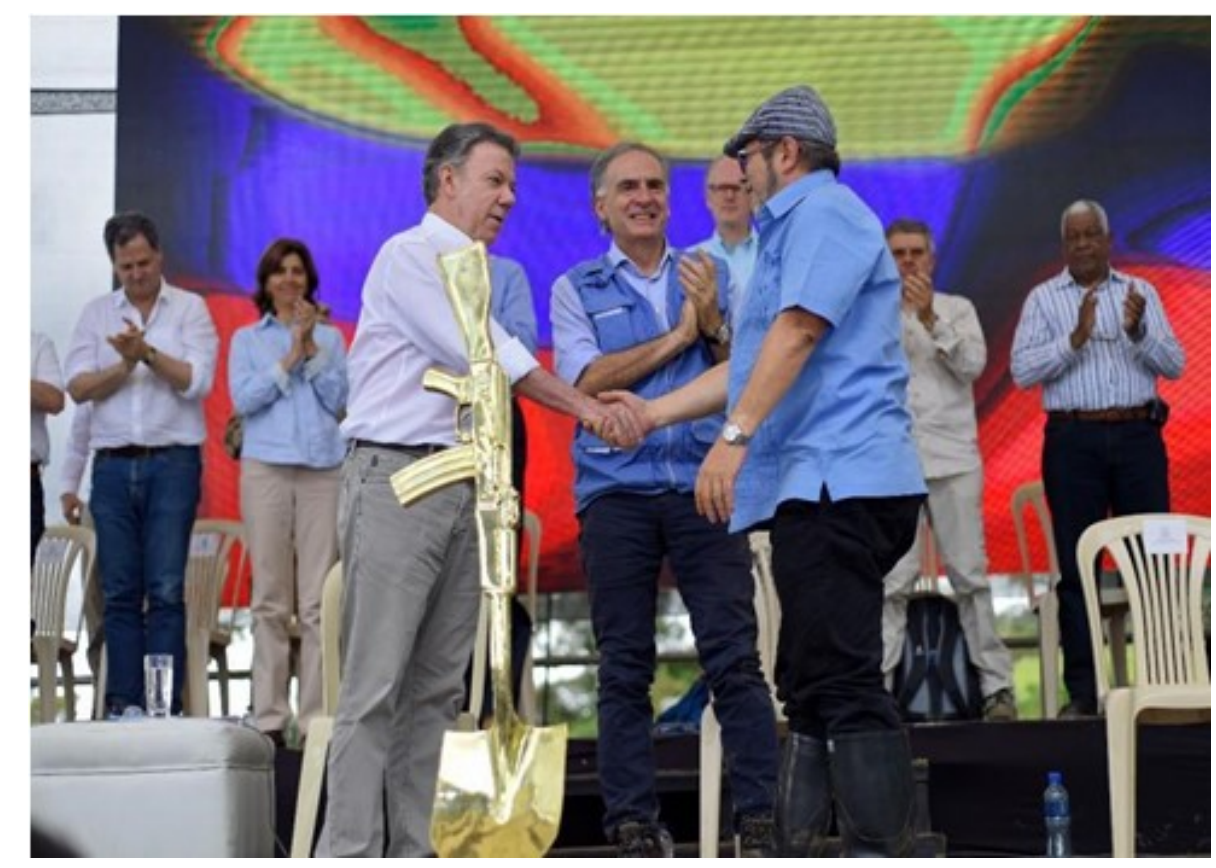

FIGURA 4.

El ritual de la entrega.

Fuente: Herrera (28 de junio de 2017). 


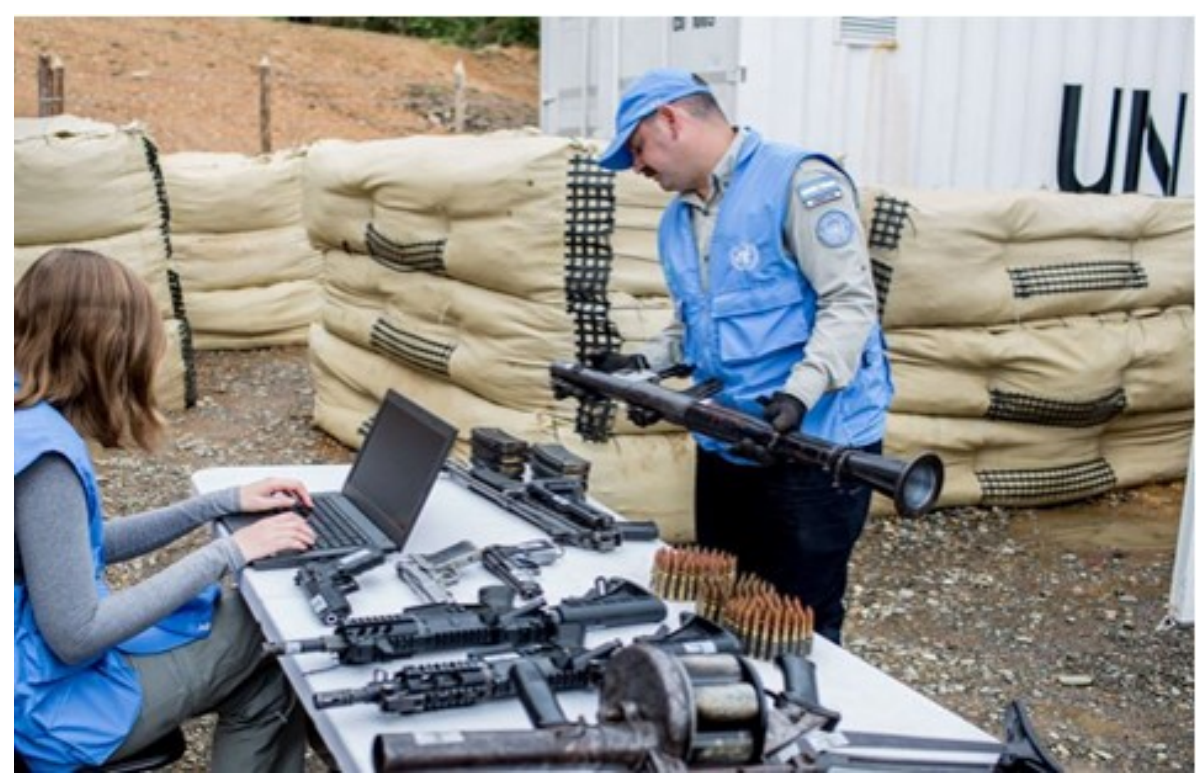

FIGURA 5.

La ONU como parte esencial del ritual. Fuente: Telesurtv (2017).

Estos dos momentos de tránsito, vistos con las debidas reservas temporales y resonancias históricopolíticas, invitan a reflexionar sobre varios asuntos. Una promesa de paz deviene siempre en un acto de fe en un conjunto de ofertas hechas desde un poder político, con una carga hegemónica bastante diferenciada, respecto al que recibe la promesa de paz o la ilusión del porvenir ${ }^{14}$. En la promesa, puede haber confianzas en una palabra dada y en un ideario político central, como fue el caso de Eulogio Fonseca, pero también tensiones medianamente resueltas con el paso del tiempo y sobre todo con el respaldo internacional, como en el caso de las FARC. En ambos casos, no obstante, siempre quedarán desconfianzas latentes que el paso del tiempo se encargará de ratificar.

La promesa no aparece en el vacío, sino que se surte dentro de un ritual político y social, con efectos performativos en ciertas coyunturas, cumpliendo una función hipersimbolizadora que a la vez que abre, también obtura la comprensión de lo sucedido. Hace 64 años, la paz se hipersimbolizó a través de una política de pacificación territorial que se promocionó por todos los medios de la época, y en la que se ofreció libertad, orden y justicia. La paz ofertada, fue una paz militar, que se vendía como generosa con los bandidos. Hoy, el proceso de paz con las FARC ha operado en un marco de negociación diferente, con el reconocimiento de la beligerancia de un actor y la existencia de un conflicto armado, político y social y la necesidad de que ella sea duradera y sostenible, después de más de 50 años de guerra. No obstante, hay un elemento que continúa en ambas promesas y es el de la pacificación. Quizá con otros sintagmas y modos de enunciación, la pacificación de hoy es la de la paz liberal, muy poco cuestionada por la institucionalidad y las burocracias de lo transicional ${ }^{15}$.

La promesa exige repetición y demanda reiteración de ciertas convenciones o estéticas (Taylor, 2012), también de "órdenes" (Van Gennep, 2008), de ciertas teatralidades (Diéguez, 2007), y por supuesto, como en todo ritual, reactualización de tiempo en tiempo. En ese proceso ritualístico, las imágenes procuran un efecto de verdad. La prensa y el archivo cumplen su parte cabal allí. Cada detalle del acto de entrega o de la ceremonia de firma de un acuerdo, pareciera como dispuesto para que la promesa se entienda como algo que no es etéreo, sino que tiene sus custodios, hay en esta promesa una escenificación de un poder institucional desplegado de diversas formas. Por ejemplo, la presencia constante de tenientes, coroneles y mayores en los actos protocolarios de la entrega de armas o en sus conversaciones con la guerrillerada, como es muy común en las imágenes del Archivo Germán Guzmán Campos; o la sonrisa del estadista que ve su "sueño de paz 
cumplido" o la de los guerrilleros de alto rango que también sonríen, pero no dejan de ser escépticos, como en el caso del último proceso. Cada imagen y ritual quieren dar la impresión de que esta paz si puede ser altamente efectiva y patriótica. Nótese que las dos últimas metáforas, sirven para enunciar que de ella puede nacer un proyecto de país pacificado y próspero, totalmente distinto al proyectado por el bandolerismo o el terrorismo.

Sobre esta ilusión de que la paz puede ser altamente promisoria, fecunda y próspera para todos, vale comentar que, al revisar las más de 160 fotografías del Archivo Guzmán Campos sobre el desarme de las guerrillas llaneras, casi todas de militares y guerrilleros posando para la política de pacificación emergieron unas poquísimas fotos (solo tres) donde aparecían las mujeres de los guerrilleros liberales, etiquetadas también en muchos casos como bandoleras. Una en particular en la que aparecen tres mujeres, un niño y Guadalupe Salcedo, llamó la atención (Figura 6). Dichas mujeres armadas, que están a los lados y posan para la foto, podrían representar esa promesa de que la paz también podía incluirlas a ellas, a sus familias. Algo que, cómo se verá luego, fue solo eso, una promesa.

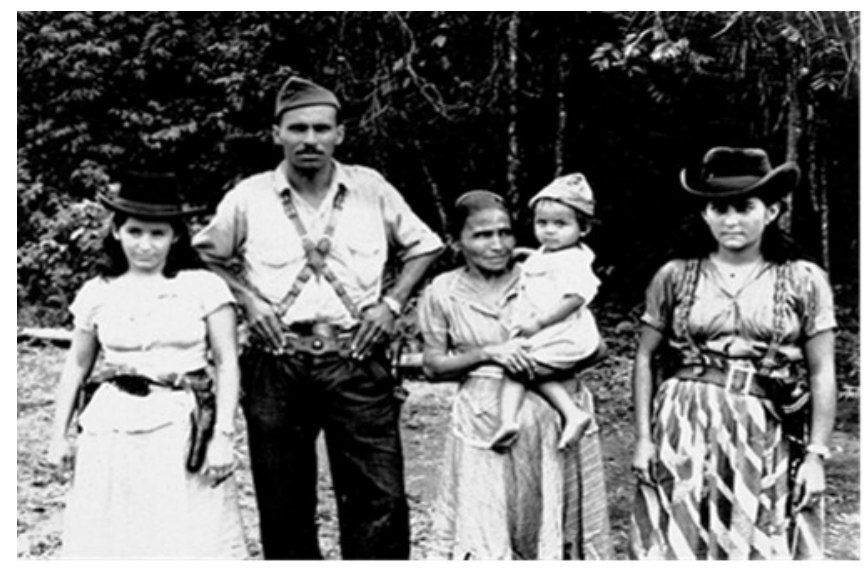

FIGURA 6.

Familia de Guadalupe Salcedo: compañera, madre e hijo. Aparece también Lucila Toro, compañera del teniente guerrillero Marco Antonio Torres. Fuente: Archivo Germán Guzmán Campos (2019).

Comprender críticamente la promesa y el ritual de tránsito, es reconocer lo que se quiere presentar o recrear hegemónicamente. Por ejemplo, las imágenes de contenedores de armas clasificadas y etiquetadas, las imágenes de una entrega a un militar de alto rango del Estado de aquella arma preciada que ha acompañado durante mucho tiempo a un guerrillero, o las fotografías de las manos estrechadas entre el estadista y el guerrero emblemático. Esta última imagen y performance, resulta bien sugerente. El apretón de manos como sellando un pacto entre bandos pareciera transmitir cierta efectividad y realización, pero en el fondo oblitera que muchos de los que aprietan no tienen al final la capacidad suficiente para frenar los combustibles del conflicto (desigualdad, economías ilegales, rearmes). La liturgia que sella la paz revela también su fragilidad.

La promesa moviliza sus símbolos. El día 13 de junio a las 10 p. m., día en que tomó el poder, Rojas Pinilla en alocución radial anunció su oferta institucional de pacificación que tenía pensada para el país. Días después utilizó la estrategia psicológica de volantear el Llano arrojando, desde aviones de la Fuerza Área en distintas zonas donde había guerrillas, mensajes escritos para informar sobre el golpe militar y anunciar la promesa de paz para los que depusieran sus armas. Durante el Gobierno de Uribe, proclive más a una paz militar, la promesa de paz que se vendía constantemente iba con la consigna "guerrillero desmovilízate, tu familia te espera en casa".

La promesa pasa por entender que nuestra paz institucional no ha estado exenta de coacción y engaño y ha sido poco transparente. Traigamos a colación esta viñeta histórica del primer momento. En la zona de Monterrey, Casanare, días antes de darse la primera entrega de armas (Figura 1), se congregaron allí 31 comandantes guerrilleros para presentar al Gobierno un plan de 24 puntos, entre los cuales estaban: amnistía, 
atención e indemnización a los habitantes, depuración de las Fuerzas Armadas, atención médica, libertad para presos políticos, regreso de los exiliados y devolución de tierras expropiadas. El Gobierno, con la justificación de "no dar un paso a torcer en su afán por pacificar el país", hizo que estos 31 hombres fueran desarmados por 500 soldados armados bajo la "promesa de libertad y cese de persecución" una vez entregadas las armas (Ramírez, 2018; Valencia, 2018). Este acontecimiento, conocido como la Encerrona de Monterrey, fue un deliberado acto de provocación, por no decir de traición, a la promesa que decía cumplir, la de libertad y no persecución. Sin embargo, al Gobierno de Rojas, el salvador de Colombia como reza en la Figura 7, poco le importó acometer este acto y lo justificó como esencial para tener la llave de la guerra y sellar la paz, sin más dilaciones.

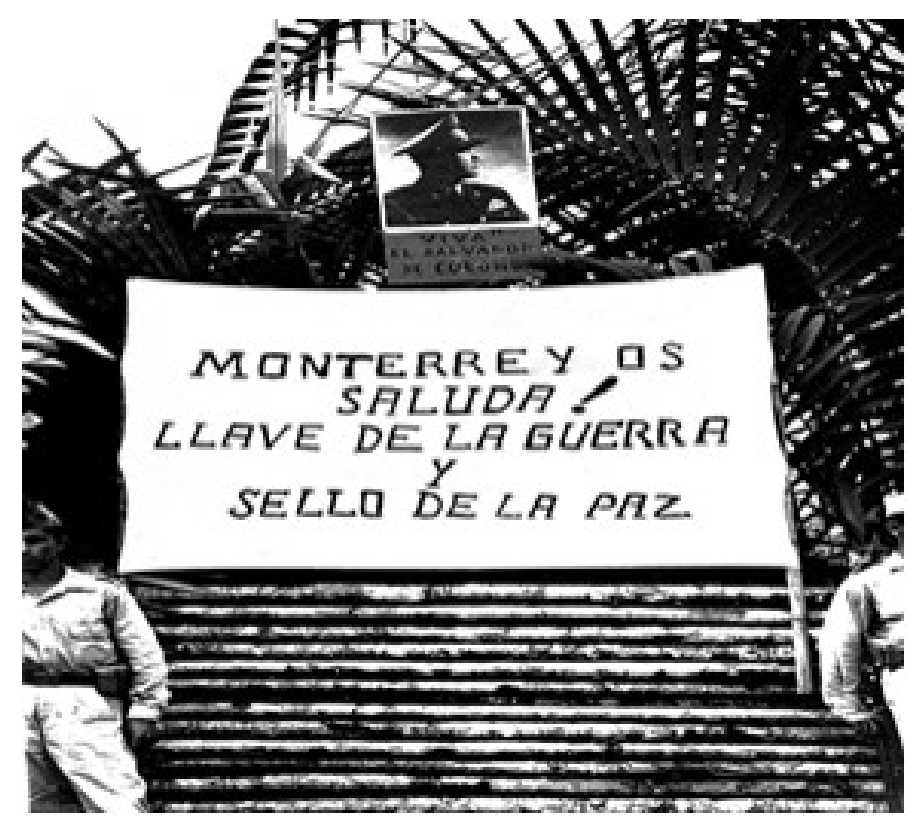

FIGURA 7.

Monterrey "llave de la guerra y sello de la paz".

Fuente: Archivo Germán Guzmán Campos (2019).

\section{La ilusión: la última marcha y la imaginación e incertidumbre de una nueva vida}

Un acuerdo de paz posibilita ciertas esperanzas para imaginar un porvenir ${ }^{16}$. Sin embargo, los procesos de paz siempre ponen en evidencia las tensiones y brechas irresolubles entre la ilusión social de la promesa y la incertidumbre respecto a la implementación de lo acordado. Exploremos esto a partir de dos noticias que circularon en 2017 y 1953.

En febrero de 2017, unos meses antes de haberse llevado la última entrega de armas de las FARC, la revista Semana, en pleno clímax del acuerdo de paz, abría su publicación periódica con el siguiente titular: "La última marcha de las Farc". La imagen de la portada, de autoría del reconocido fotógrafo Jesús Abad Colorado, mostraba a guerrilleros y guerrilleras descendiendo de canoas y en primera plana a una mujer guerrillera cargando un bebé. En el artículo, se decía que este acontecimiento "quedaría en la memoria de los colombianos como uno de los hechos más importantes de la historia reciente", dado que desde todas partes y por distintos medios: lanchas (Figura 8), buses, carros escaleras, camiones y hasta a pie, "unos 4.761 guerrilleros se estaban movilizando hacia las zonas veredales pactadas con el Gobierno para dejar las armas y empezar su tránsito a la vida civil" [cursivas fuera del texto]. El artículo enfatizaba, además, que los y las guerrilleras, "traían a 
cuestas unos pocos enseres, algunos animales, perros, cerdos y pájaros, y una historia de guerra que quieren dejar atrás" (Semana, 4 de febrero de 2017) [cursivas fuera del texto].

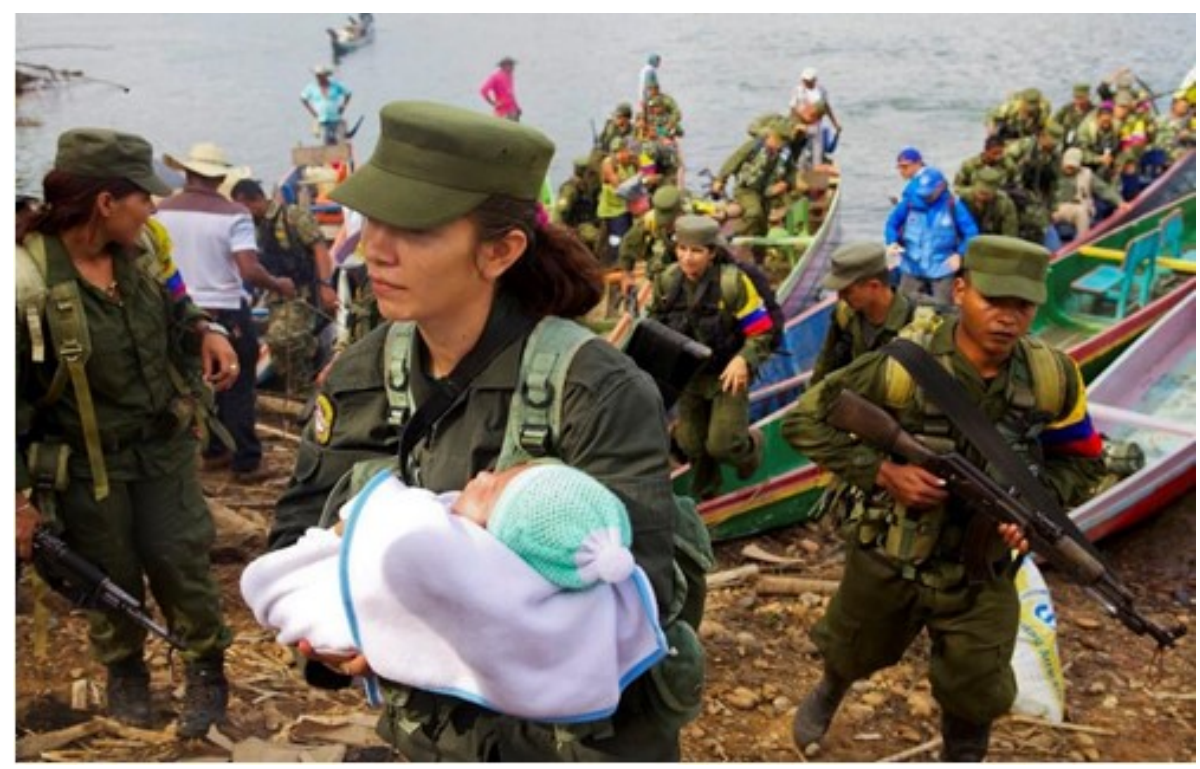

FIGURA 8.

La última marcha de las FARC.

Fuente: Portada de Jesús Abad Colorado (2 de abril de 2017).

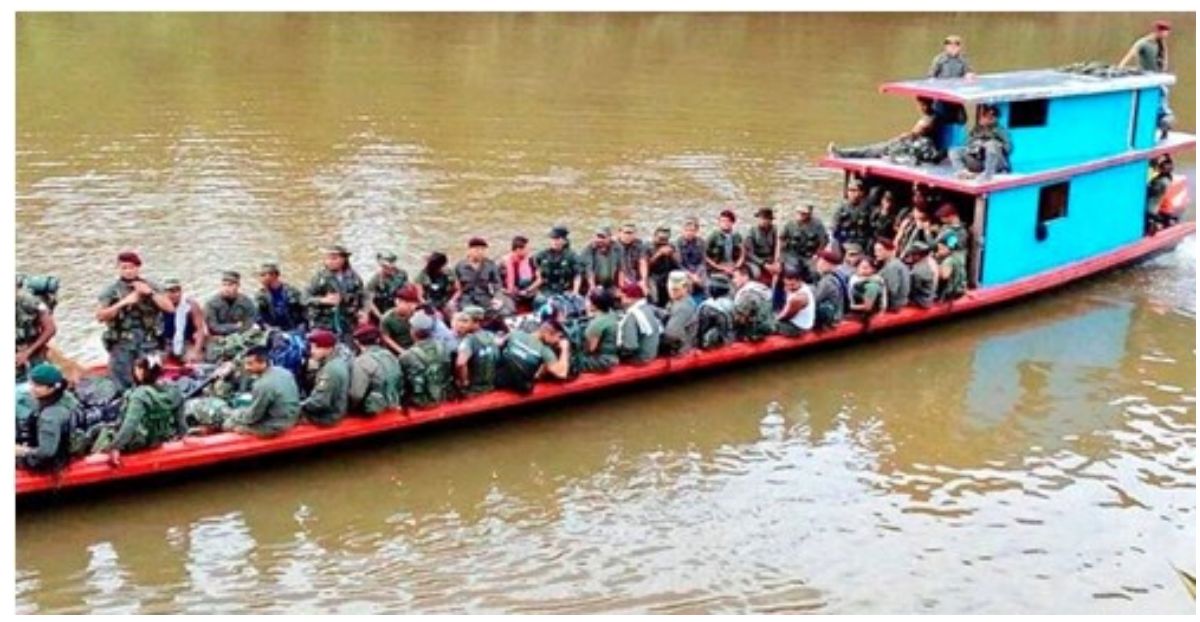

FIGURA 9.

Otra manera de recrear la última marcha.

Fuente: Semana (2 de abril de 2017).

Años antes, el 12 de septiembre del 53, el periódico El Tiempo, haciendo alusión a la operación de paz del Gobierno de Rojas, desplegaba un enorme titular que decía "El regreso a la Normalidad en el Llano". El contenido de la noticia que acompañaba al titular era bien significativo. Ahondaba sobre el logro principal de esta operación: "silenciar los fusiles y cesar la fiebre de matar", y sentenciaba para el país que ante lo "fiero del plomo" lo que se había impuesto era "el ángel de la paz sobre una tierra mártir, erguida y legendaria" ( $E l$ Tiempo, 12 de septiembre de 1953). Aunque no se dijo en la noticia, la metáfora del ángel era utilizada seguramente para calificar la obra de Rojas Pinilla, como ya se había hecho en otras imágenes de la época donde se le presentaba como el Salvador de Colombia (Figura 10). La fotografía que acompañaba al titular también era la de una gran marcha, esta vez de cientos de llaneros, sin bienes a cuestas, solo con sus fusiles. 


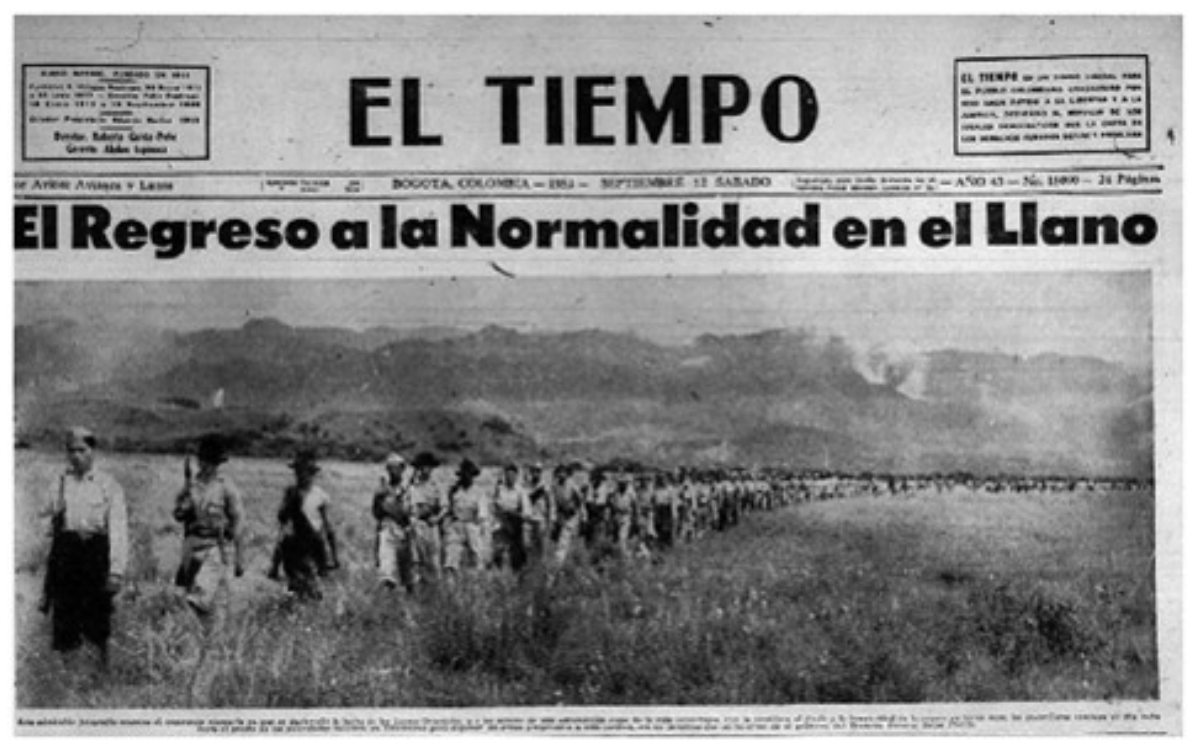

FIGURA 10.

La Gran Marcha del 53.

Fuente: El Tiempo (12 de septiembre de 1953).

A propósito de la conmemoración de los 60 años de la entrega llanera y bajo la coyuntura del proceso con las FARC, el periódico El Tiempo reactualizaría la imagen del 53, mostrando esta vez y más de cerca, jóvenes descalzos y harapientos, marchando con cierto asomo de asombro e incertidumbre hacia la pacificación (Figura 11).

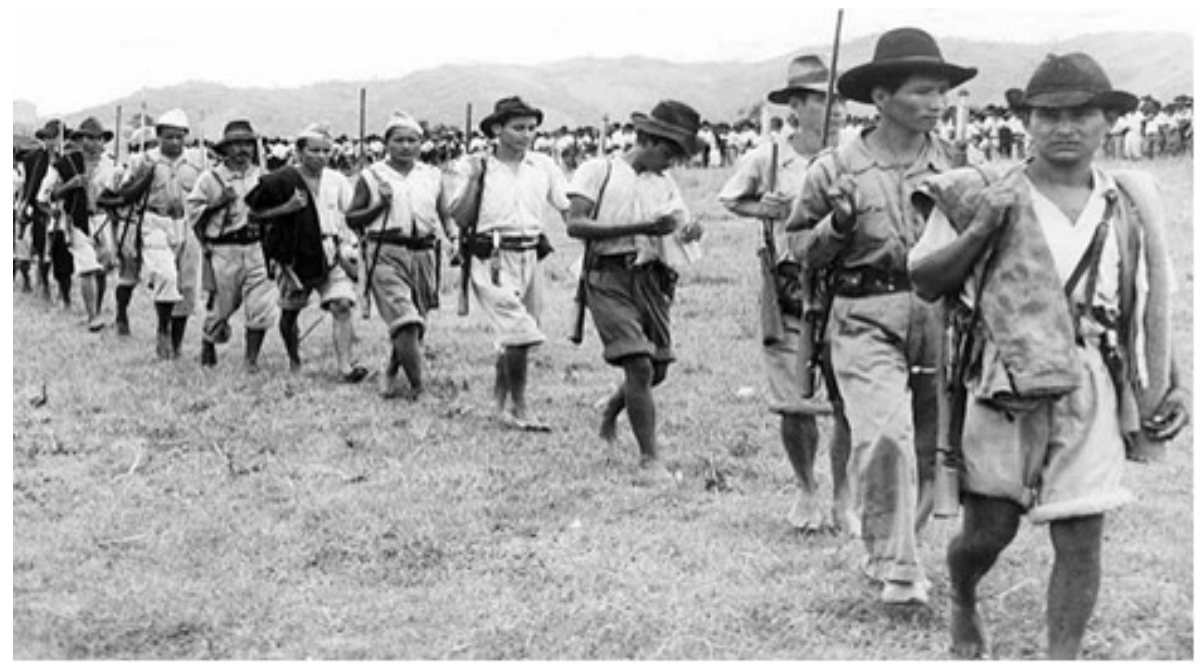

FIGURA 10

La Gran Marcha del 53.

Fuente: El Tiempo (12 de septiembre de 1953).

¿Cómo leer la ilusión en esos dos momentos? La respuesta a ello es dura pero real: la paz se ha tornado, muchas veces para el que la firma, en una especie de kit básico de sueños, llenado unas veces de asistencia estatal, otras de un repertorio de bondades transicionales de lo que vendrá tras la renuncia a la guerra. La marcha otorga sentido performático a esos sueños.

En el caso del proceso de paz de Rojas Pinilla, marchando hacia un mundo normalizado los otrora bandoleros serán acreedores de ese kit, a cambio de armas, entrega de hombres y fidelidad al ideario reconciliador del Gobierno. A propósito de esto, guerrilleros amnistiados recordaban como, a cambio de 
fusiles, los militares les entregaban una bolsa de papel con algunos objetos como una libra de frijol, una camisa, un pantalón, un sombrero de paja, cigarrillos, azúcar, unas quimbas o cotizas llaneras, una peinilla y 2000 pesos de la época (Alape, 1985; Mayorga, 2015; Valencia, 2018).

Por su parte, con la imagen de La última marcha de las FARC se pueden tensar dos escenarios. Para el lente de la paz liberal, el recorrido es hacia un nuevo comienzo para hombres y mujeres que alguna vez le apostaron al terrorismo y ahora tienen la posibilidad de renunciar definitivamente a esto, para dedicarse a constituir hogares, educar a sus nuevos hijos y labrar la tierra. Desde los testimonios de excombatientes, el tránsito es hacia la reconexión con lo que abandonaron cuando entraron a la militancia armada. Existen varias notas periodísticas que publicó el periódico El País en 2019, mostrando cómo para las mujeres farianas, esta reconexión pasa por "terminar el bachillerato", "estudiar lo que siempre han querido, por ejemplo, una ingeniera agronómica" y hacer que sus padres e hijos "se sientan orgullosos" (El Espectador, 2016; El País, 2016, 2019).

Los acontecimientos que vendrán en la etapa de reinserción mostrarán las fisuras y la simulación de este paquete de ilusiones. Valencia (2018) muestra a propósito que lo que sucedió tras la entrega de armas en los Llanos reveló que las condiciones sociales que dieron origen a la revolución llanera no variaron significativamente. Rojas Pinilla y los gobiernos sucesivos incumplieron sus promesas y la reconstrucción económica de las zonas afectadas. Esta última había sido la gran ilusión para las poblaciones locales, y esto se quedó a medio camino. Los caciques regionales recuperaron el control del poder local e impulsaron una persecución contra los sectores que seguían en la lucha por mejores condiciones o contra los antiguos combatientes. Guadalupe Salcedo sería asesinado en Bogotá, el 6 de junio de 1957 y Dumar Aljure, quien había regresado a la lucha por el incumplimiento de las promesas, moriría sitiado por el Ejército el 5 de abril en el Meta.

Evaluando el actual proceso de paz, la Secretaría Técnica del Componente de Verificación Internacional a la Comisión de Seguimiento, Impulso y Verificación a la implementación de los Acuerdos de Paz de la Habana ([STCSIVI], 2019) ha llamado la atención sobre cómo de los seis puntos pactados, los mayores avances dentro del proceso de implementación se han encontrado en el punto 6, lo relacionado con la comisión de seguimiento, verificación y refrendación, y en el punto 5 lo relacionado con la conformación y operación de instancias como la Jurisdicción Especial para la Paz, la Comisión de la Verdad y la Comisión de Búsqueda de Personas dadas por desaparecidas. El resto de los puntos ha tenido una implementación reducida, incipiente o nula (punto 1, reforma rural; punto 2, participación política; punto 3, DDR, punto 4, solución del problema de drogas ilícitas).

Las dificultades de este último proceso en su fase de implementación no son pocas y las razones son diversas y muchas de ellas se reactualizan luego de 64 años. Unas están vinculadas a la falta de voluntad política del actual gobierno para llevar a cabo la promesa del anterior. Otras están asociadas a la reconfiguración de las dinámicas de una nueva fase del conflicto armado en diversos territorios del país, o a las disputas entre grupos armados ilegales por el control de rutas de armas y drogas. Varias también tienen que ver con las condiciones de vida tan precarias e inseguras en los Espacios Territoriales de Capacitación y Reincorporación, donde para muchos se terminó confinando la esperanza. Sin embargo, donde está la mayor dificultad ha sido nuevamente, como lo fue en su momento para las guerrillas del Llano, en la seguridad y la protección de la vida de los que optaron por la ilusión de la paz. De hecho, entre la firma del Acuerdo de Paz en noviembre de 2016 y mayo de 2019, 129 excombatientes fueron asesinados (Alvarado, 2019). Al término de este artículo, iban 14 excombatientes asesinados en 2020. 


\section{Epílogo (viñetas para seguir reflexionando)}

En el año 2017, en una visita realizada por uno de los autores de este texto a la antigua Zona Veredal Transitoria de Normalización Carlos Perdomo en Caldono (Cauca), ubicada en la vereda San Antonio de los Monos, donde se congregaban para ese momento 510 farianos y farianas, fue posible evidenciar algo que podría ser expresión de cómo, a pesar de que la utopía y la distopía siempre están tensadas y en litigio en estos procesos de paz, la gente del común que le apostó a la paz, sigue conservando la confianza y la esperanza. Entre el barro, la escasez de alimentos, el limitado acceso a servicios básicos como agua o electricidad, la falta de garantías de seguridad, y muchos "cambuches" de lona y madera que servían como hogares provisionales para quienes allí se encontraban, el punto nodal de todas las conversaciones siempre giró en torno a la ilusión del nuevo comienzo, a la posibilidad de un futuro distinto.

No obstante, la ilusión de la esperanza si bien cohesiona y da cuenta de la búsqueda de un futuro compartido distinto al de la guerra, también engloba distopía. Contiene tanto de posibilidad como de espejismo. La gradualidad entre lo uno y lo otro depende de la voluntad de las partes, pero sobre todo de la realización efectiva de las condiciones ofertadas por el Estado. Son muchos los autores que han insistido en que para romper con la distopía se necesitan garantías de dignificación, de seguridad, de sostenibilidad económica, de acceso real a derechos políticos (Arjona et al., 2020; Mouly et al., 2019). Y ello pasa por materializar las ilusiones: el sueño de tener una vivienda, la recuperación de una familia, la construcción de un futuro compartido con un compañero o compañera de vida, el retornar en paz al campo, el poder salir a la calle con toda confianza, el no ser nuevamente violentados.

\section{Referencias}

Abad Colorado, J. (2 de abril de 2017). Semana [Fotografía]. https://www.semana.com/nacion/articulo/farc--se-con centraron-en-zonas-veredales/514346/

Aguirre, K., Álvarez, E., y Pardo, D. (2015). Desarme de las Farc. Claves y propuestas para un proceso viable, exitoso y transparente. Fundación Ideas para la Paz, Instituto Igarapé.

Alape, A. (1985). La paz, la violencia: testigos de excepción. Planeta.

Alvarado, S. (8 de mayo de 2019). Los asesinatos de exguerrilleros comprometen la paz en Colombia. The New York Times. https://www.nytimes.com/es/2019/05/08/asesinatos-exguerrilleros-colombia.html

Archivo Fotográfico Germán Guzmán Campos. (2019). Universidad del Valle, Programa Editorial.

Arjona, A., Fergusson, L., Garbiras, N., García, J., Hiller, T., Polo, L., y Weintraub, M. (julio, 2020). Actitudes de exintegrantes de las FARC-EP frente a la reincorporación (Documento del Centro de Estudios sobre Desarrollo Económico N. . 24). https://economia.uniandes.edu.co/publicaciones/dcede2020-24.pdf

British Broadcasting Corporation. (1 de diciembre de 2016). Colombia: el Congreso aprueba el nuevo acuerdo de paz con las FARC y las divisiones se trasladan a las presidenciales de 2018. https://www.bbc.com/mundo/noticias-a merica-latina-38165978

Bonilla Vélez, J. (2019). La barbarie que no vimos: fotografia y memoria en Colombia. Universidad EAFIT.

Cabrera, M. (2006). Medios de comunicación y medios visuales en los conflictos armados en la posguerra fría. OASIS, 12, 119-140. https://revistas.uexternado.edu.co/index.php/oasis/article/view/2414

Cabrera, M. (2008). Guerra de imágenes, imágenes de guerra: cuatro eventos mediáticos de la guerra de Iraq. OASIS, 13, 61-88. https://revistas.uexternado.edu.co/index.php/oasis/article/view/2443

Castillejo, A. (2015). La imaginación social del porvenir: reflexiones sobre Colombia y el prospecto de una Comisión de la Verdad. Consejo Latinoamericano de Ciencias Sociales.

Cruz, J., y Fontan, V. (2014). Una mirada subalterna y desde abajo de la cultura de paz. Ra Ximhai, 10(2), 135-152. h ttp://www.revistas.unam.mx/index.php/rxm/article/view/71182/62885 
De la Calle, H. (2019). Revelaciones al final de una guerra. Debate.

Diéguez, I. (2007). Escenarios liminales. Teatralidades, performances y política. Atuel.

Didi-Huberman, G. (2012). Quando as imagens tocam o real. PÓS, Revista do Programa de Pós-graduação em Artes da Escola de Belas Artes da EBA/UFMG, 2(4), 206-219. https://periodicos.ufmg.br/index.php/revistapos/arti cle/view/15454

Doyle, M. (2005). Three pillars of the liberal peace. The American Political Science Review, 99(3), 463-466. www.jstor.org/stable/30038953

El Espectador. (17 de septiembre de 2013). 60 años de un proceso de paz [Fotografía]. https://www.elespectador.com /noticias/nacional/60-anos-de-un-proceso-de-paz-446792

El Espectador. (19 de octubre de 2016). El diario de las mujeres de las Farc después del plebiscito. https://www.elespectador.com/colombia2020/pais/el-diario-de-las-mujeres-de-las-farc-despues -del-plebiscito-articulo-854892/

Fajardo, J. (2009). Por la paz de Colombia el EPL dispuso sus armas a discreción de la Constituyente. En Á. Villarraga (Ed.), Biblioteca de Paz 1990-1994. Acuerdos con el EPL, PRT, MAQL y CRS. Diálogos con la CGSB (pp. 45-51). Fundación Cultura Democrática/Organización Internacional para las Migraciones.

FARC-EP. [@FARC_EPueblo]. (2017).NC FARC [Fotografía]. https://www.elespectador.com/noticias/nacional/ la-ue-celebra-el-irreversible-proceso-de-paz-en-colombia-700406/

Fattal, A. (2019). Guerrilla marketing: contrainsurgencia y capitalismo en Colombia. Editorial Universidad del Rosario.

Fayet, A., y Gordillo, C. (2017). Naturalizar a militarização: repetição, vigilância e espetáculo nas fotografias de guerra na Colômbia. Revista Sans Soleil. Estudios de la Imagen, 9, 94-114. http://revista-sanssoleil.com/wp-content/u ploads/2017/09/Fayet-Gordillo.pdf

Fisas, V. (1998). Cultura de paz y gestión de conflictos. Icaria.

Fontan, V. (2013). Descolonización de la paz. Pontificia Universidad Javeriana.

Franco, E. (1994). Las guerrillas del Llano. Planeta.

Galtung, J. (1990). Cultural violence. Journal of Peace Research, 3(27), 291-305. https://doi.org/10.1177/00223433 90027003005

Galtung, J. (1996). Peace by peaceful means: Peace and conflict, development and civilization. Sage.

Giraldo, J., y Mesa, J. P. (2013). Reintegración sin desmovilización: el caso de las milicias populares de Medellín. Colombia Internacional, 77, 217-238. http://www.scielo.org.co/pdf/rci/n77/n77a08.pdf

Gleichmann, C., Odelwald, M., Steeken, K., y Wilkinson, A. (2004). Desarme, desmovilización y reintegración. Guia teórica y práctica. Colegio Sueco para Defensa Nacional/Centro Noruego para Defensa Internacional/Centro Canadiense Pearson para el Mantenimiento de la Paz/Cooperación Técnica Alemana.

Gómez-Suárez, A. (2016). El triunfo del No: la paradoja emocional detrás del plebiscito. Ícono.

Grabe, V. (2009). Renunciar a las armas: el rechazo de la violencia por parte del M-19 en Colombia. En C. Buchanan (Ed.), Puntos de vista. Reflexiones sobre armas, combatientes y violencia armada en procesos de paz (pp. 20-33). Centro para el Diálogo Humanitario.

Guarín, O. (2019). Violencia, imagen y (re)significación. En C. Salamanca y J. Jaramillo (Eds.), Politicas, espacios $y$ prácticas de memoria. Disputas y tránsitos actuales en Colombia y América Latina (pp. 295-317). Pontificia Universidad Javeriana.

Guzmán, G., Fals Borda, O., y Umaña, L. (1962). La violencia en Colombia. Estudio de un proceso social. Tercer Mundo.

Herrera, D., y González, P. (2013). Estado del arte del DDR en Colombia frente a los estándares internacionales en DDR (IDDRS). Colombia Internacional, 272-302. https://doi.org/10.7440/colombiaint77.2013.10

Herrera, E. (28 de junio de 2017). El Espectador [Fotografía]. https://www.elespectador.com/noticias/nacional/la-u e-celebra-el-irreversible-proceso-de-paz-en-colombia-700406/

Jaimes, A. (27 de enero de 1991). El PRT: las armas y el mar. El Tiempo. http://www.eltiempo.com/archivo/docum ento/MAM-15856 
Joya, A. (2015). Desarme en procesos de paz: análisis preliminar del caso colombiano (Documento de Investigación N.ำ 2). https://www.urosario.edu.co/ODA/Publicaciones/Documentos-de-investigacion/

Knight, A. (2008). Disarmament, demobilization, and reintegration and post-conflict peacebuilding in Africa: An overview. African Security, 1(1), 24-52. https://doi.org/10.1080/19362200802285757

Mayorga, D. (24 de enero de 2015). Entrevista con la historia: los guerrilleros de la revolución llanera. Pacifista! https ://pacifista.tv/notas/entrevista-con-la-historia-los-guerrilleros-de-la-revolucion-llanera/

Mc Ginty, R. (2014). Everyday peace: Bottom-up and local agency in conflict-affected societies. Security Dialogue, 45(6), 548-564. https://doi.org/10.1177/0967010614550899

Mouly, C., Hernández, E., y Giménez, J. (2019). Reintegración social de excombatientes en dos comunidades de paz en Colombia. Análisis Politico, 32(95). https://doi.org/10.15446/anpol.v32n95.80822

Muñoz, F. (2004). La paz imperfecta. En M. López (Dir.), Enciclopedia de paz y conflictos: L-Z (Vol. 2, pp. 898-900). Universidad de Granada.

Nussio, E. (2012). La vida después de la desmovilización: percepciones, emociones y estrategias de exparamilitares en Colombia. Uniandes.

Nussio, E. (2013). Desarme, desmovilización y reintegración de excombatientes: políticas y actores del posconflicto. Colombia Internacional, 77, 8-16. https://doi.org/10.7440/colombiaint77.2013.01

Olaya, D. V. (2020). Las imágenes de las víctimas del conflicto armado en la revista Semana: políticas, significados culturales y visibilización. Palabra Clave, 23(1), e2316. https://doi.org/10.5294/pacla.2020.23.1.6

El País. (13 de septiembre de 2016). Retratos del conflicto en Colombia. https://elpais.com/elpais/2016/09/12/album /1473674435_528175.html\#foto_gal_1

El País. (15 de diciembre de 2019). De la guerra a la academia: 35 exguerrilleros de las Farc se graduaron como bachilleres. https://www.elpais.com.co/colombia/de-la-guerra-a-la-academia-35-exguerrilleros-de-las-farc-se-gr aduaron-como-bachilleres.html

Pares. Fundación Paz y Reconciliación. (2019). Procesos de paz en Colombia. https://pares.com.co/2019/01/04/proc esos-de-paz-en-colombia/

Pérez de Armiño, K., y Zirion, I. (Coords.). (2019). Pax crítica. Aportes teóricos a las perspectivas de paz posliberal. Tecnos.

Pizarro, E. (2004). Una democracia asediada: balance y perspectiva del conflicto armado en Colombia. Norma.

Presidencia de la República de Colombia. (2017). \#DejaciónDeArmas. http://especiales.presidencia.gov.co/Docume nts/20170620-dejacion-armas/dejacion-de-armas.html

Presidencia de la República de Colombia. (2018). Biblioteca del Proceso de Paz 2010-2018 (Vols. 1-11). Presidencia de la República, Oficina del Alto Comisionado para la Paz.

Ramírez, F. (2018). Las guerrillas de los Llanos Orientales. Cronología. En E. Zapata, L. C. Castillo, A. Valencia y F. Ramírez (Comps.), Entrega de armas de las guerrillas del Llano, Sep.- Oct. 1953 (pp. 25-285). Universidad del Valle.

Resumen Latinoamericano. (14 enero, 2020). Colombia. Declaración Política de la comandancia de las FARC-EP, Segunda Marquetalia. https://www.resumenlatinoamericano.org/2020/01/14/colombia-declaracion-politicade-la-comandancia-de-las-farc-ep-segunda-marquetalia/

Richmond, P. O. (2006). The problem of peace: Understanding the 'liberal peace'. Conflict, Security \& Development, 6(3), 291-314. https://doi.org/10.1080/14678800600933480

Richmond, P. O. (2011). Resistencia y paz postliberal. Relaciones Internacionales, 16, 13-45. https://revistas.uam.es/ relacionesinternacionales/article/view/5062/5520

Schulhofer-Wohl, J., y Sambanis, N. (2010). Disarmament, demobilization, and reintegration programs: An assessment (Informe de investigación). Folke Bernadotte Academy Publications. https://ssrn.com/abstract=1906329

Taylor, D. (2012). Performance. Asunto Impreso.

Taylor, D. (2011). Introducción. Performance, teoría y práctica. En D. Taylor y M. A. Fuentes (Eds.), Estudiosavanzados de performance (pp. 6-30). Fondo de Cultura Económica. 
Telesur. (13 de junio de 2017). FARC-EP completan dejación del $60 \%$ de su armamento a la ONU [Fotografía]. https://www.telesurtv.net/news/ONU-confirma-que-tiene-el-60--de-las-armas-de-las-FARC-EP -20170616-0071.html

Theidon, K., y Betancourt, P. (2006). Transiciones conflictivas: combatientes desmovilizados en Colombia. Revista Análisis Politico, 58, 92-111. https://revistas.unal.edu.co/index.php/anpol/article/view/46264/47868

El Tiempo. (12 de septiembre de 1953). El regreso a la normalidad en el Llano [Fotografía]. https://www.eltiempo.c om/archivo/documento/MAM-181642

Uribe, M. T. (1997). Antioquia: entre la guerra y la paz en la década de los 90. Estudios Politicos, 10, 126-137. https:/ /revistas.udea.edu.co/index.php/estudiospoliticos/article/view/16149

Urrutia, N., Ortega, M., Andrade, G., y Vranckx, A. (2009). Rastreo de armas. Perspectivas sobre control, tráfico y uso de armas ilegales en Colombia. Fundación Ideas para la Paz.

Valencia, A. (2018). La entrega de armas de las guerrillas de los Llanos Orientales. En E. Zapata, L. C. Castillo, A. Valencia y Francisco Ramírez (Comps.), Entrega de armas de las guerrillas del Llano, Sep.- Oct. 1953 (pp. 17-43). Universidad del Valle.

Valencia, G. (2007). Reconstrucción analítica del proceso de desarme, desmovilización y reinserción con las Autodefensas Unidas de Colombia, 2002-2007. Perfil de Coyuntura Económica, 10, 147-191. https://www.red alyc.org/articulo.oa?id=86112678006\&idioma $=$ es

Van Gennep, A. (2008). Los ritos de paso. Alianza.

Verzero, L. (2020). Construcción performativa de la autoridad: entramado de sentidos en apariciones públicas, imágenes y representaciones de Videla. Kamchatka. Revista de Análisis Cultural, 15, 217-241. https://ojs.uv.es /index.php/kamchatka/article/view/15748/15450

Villamizar, D. (1997). Un adiós a la guerra. Memoria histórica de los procesos de paz. Planeta.

Villanueva, O. (2012). Guadalupe Salcedo y la insurrección llanera, 1940-1957. Universidad Nacional de Colombia.

Villarraga, Á. (2013). Experiencias históricas recientes de reintegración de excombatientes en Colombia. Colombia Internacional, 77, 107-140. https://doi.org/10.7440/colombiaint77.2013.05

Villarraga, Á. (Comp.). (2009). Biblioteca de la Paz 1990-1994. Acuerdos con el EPL, PRT, MAQL y CRS: diálogos con la CGSB (1. ${ }^{a}$ ed., Vol. 3). Gente Nueva/Fundación Cultura Democrática/Organización Internacional para las Migraciones.

Zapata, E., Castillo, L. C., Valencia, A., y Ramírez, F. (Comps.) (2018). Entrega de armas de las guerrillas del Llano, Sep.- Oct.1953. Universidad del Valle.

\section{Notas}

* Artículo de reflexión. Derivado del intercambio académico de los autores en el marco de la estancia posdoctoral, realizada por Alexander L. Fattal entre 2015 y 2018 en la Facultad de Ciencias Sociales de la Pontificia Universidad Javeriana. La estancia fue financiada por la Universidad Javeriana (ID 7055) y coordinada por Jefferson Jaramillo dentro del grupo de investigación Política Social y Desarrollo (Categoría A1, Convocatoria Colciencias, 2018).

1 Inicialmente, el corpus comenzó siendo de "momentos de desarme", luego se extendió a otros momentos. Este corpus no es numeroso y fue arbitrariamente construido por los autores; lo engloban distintas imágenes y documentos históricos sobre las negociaciones y la entrega de armas con las guerrillas liberales durante el Gobierno de Rojas Pinilla; la entrega de armas con el M-19 durante el Gobierno de Virgilio Barco; el desarme del EPL y el MAQL durante el Gobierno de César Gaviria; la desmovilización de la las AUC entre 2003 y 2006 y, finalmente, el desarme y la desmovilización de las FARC en 2017.

2 Traducción propia.

3 Traducción propia.

4 Por ejemplo, los trabajos de Fajardo (2009), Joya (2015), Giraldo y Mesa (2013), Aguirre et al. (2015), Valencia (2007), Urrutia et al. (2009), Villarraga (2009), Jaimes (1991), Grabe (2009), Villamizar (1997), Pizarro (2004), Herrera y González (2013) y Uribe (1997). 
5 Para el caso colombiano, esto lo analiza de manera profusa el trabajo de Bonilla Vélez (2019).

6 Cabrera evidencia algo similar para la guerra de Irak (2008) y para la Guerra del Golfo (2006).

7 Según la Fundación Paz y Reconciliación (2019), en 1953, asistimos al acuerdo de paz con las guerrillas liberales. Entre 1982 y 1986, hubo acercamientos de diálogo en la Uribe (Meta) con las FARC, y de 1989 a 1990 se llevó a cabo el proceso de paz con el M-19. Entre 1990 y 1991, hubo procesos con el Ejército Popular de Liberación, el Movimiento Armado Manuel Quintín Lame y el Partido Revolucionario de los Trabajadores. En 1992, se llevó a cabo el proceso con la Coordinadora Guerrillera Simón Bolívar (en Caracas y Tlaxcala). Entre 1993 y 1994, sucedió el proceso con la Corriente de Renovación Socialista (1993-1994). Durante el Gobierno de Samper se hicieron acercamientos con el Ejército de Liberación Nacional (1997-1998) y en el de Pastrana se llevó a cabo el proceso de negociación en San Vicente del Caguán (1998-2002) y también diálogos con el ELN. Más recientemente, en el Gobierno de Uribe Vélez se dialogó con el ELN (2005-2008) y se llevó a cabo el proceso de paz con las Autodefensas Unidas de Colombia (2003-2006). Los dos últimos procesos han sido con las guerrillas de las FARC-EP (2012-2016) y con el ELN (2016-2018).

8 Los llaneros realizaron importantes aportes en otras "gestas de resistencias" antes del 9 de abril. Recuérdese su participación en las guerras de independencia o en la Guerra de los Mil Días.

9 Para comprender la "filigrana" sobre esta mesa de negociación se recomienda el libro de Humberto de la Calle (2019), uno de los testigos de excepción, por su condición de jefe negociador.

10 Carta dirigida al Señor comandante del puesto militar "Monterrey", en Zapata et al. (2019).

11 Datos extraídos de Zapata et al. (2019). Arturo Alape (1985) maneja para estas guerrillas otro dato: 3540 hombres.

12 Informe rendido por el jefe civil y militar de los Llanos, Coronel Alfonso Saiz Montoya, al excelentísimo presidente de la República, Teniente General Gustavo Rojas Pinilla, 26 de septiembre de 1953 (citado en Zapata et al., 2019).

13 Argumentamos esto porque una de las tensiones aún latentes con las disidencias, es que, según estas disidencias "nunca pactaron la entrega de armas, sino solo su dejación”. La entrega fue una "jugada del Gobierno". Ver por ejemplo este documento: Declaración Política de la comandancia de las FARC-EP, Segunda Marquetalia (Resumen latinoamericano, 14 enero, 2020).

14 Esta expresión la tomamos de Castillejo (2015). Algunas de sus ideas, aunque no se citen textualmente en este texto, han sido sugerentes para los planteamientos de este artículo.

15 Un cuestionamiento a este evangelio viene desde un enfoque bastante plural y sugerente, aunque poco homogéneo en sus apuestas: la paz decolonial. Para un acercamiento al tema, se recomienda Cruz y Fontan (2014) y Fontan (2013).

16 Castillejo (2015) aborda el asunto de la imaginación social a través de uno de sus escenarios posibles, como lo es una comisión de la verdad.

\section{Licencia Creative Commons CC BY 4.0}

Para citar este artículo: Jaramillo Marín, J., Parrado Pardo, E. P., y Fattal, A. L. (2020). Transitar hacia la paz en Colombia. Entre la promesa y la ilusión en dos experiencias históricas (1953-2017). Signo y Pensamiento, 39(77). https://doi.org/10.11144/Javeriana.syp39-77.thpc 